\title{
Interfacial conduction mechanism of cesium hydrogen phosphate and silicon pyrophosphate composite electrolytes for intermediate-temperature fuel cells
}

\author{
Ryuji Kikuchi $^{1,2)^{*}}$, Akari Ogawa ${ }^{1)}$, Takuya Matsuoka ${ }^{1)}$, Atsushi Takagaki ${ }^{1)}$, Takashi \\ Sugawara $^{1)}$, and S. Ted Oyama ${ }^{1,3)}$
}

1) Department of Chemical System Engineering, The University of Tokyo, 7-3-1 Hongo, Bunkyo-ku, Tokyo 113-8656, Japan

2) CREST, Japan Science and Technology Agency (JST)

3) Department of Chemical Engineering, Virginia Tech, Blacksburg, VA 24061

*Corresponding author:

e-mail: rkikuchi@chemsys.t.u-tokyo.ac.jp

TEL: +81-3-5841-7345 FAX: +81-3-5841-1167

(C) 2015. This manuscript version is made available under the Elsevier user license http://www.elsevier.com/open-access/userlicense/1.0/ 


\section{Abstract}

As an electrolyte for intermediate-temperature fuel cells (ITFCs), which are operative at $200^{\circ} \mathrm{C}$ to $300^{\circ} \mathrm{C}$, a composite electrolyte $\mathrm{CsH}_{5}\left(\mathrm{PO}_{4}\right)_{2} / \mathrm{SiP}_{2} \mathrm{O}_{7}$ has been investigated. The $\mathrm{CsH}_{5}\left(\mathrm{PO}_{4}\right)_{2} / \mathrm{SiP}_{2} \mathrm{O}_{7}$ composite is reported to exhibit higher conductivity than pure $\mathrm{CsH}_{5}\left(\mathrm{PO}_{4}\right)_{2}$, possibly by forming a highly-conductive new phase at the interface between $\mathrm{CsH}_{5}\left(\mathrm{PO}_{4}\right)_{2}$ and $\mathrm{SiP}_{2} \mathrm{O}_{7}$. In this study, we have prepared several $\mathrm{SiP}_{2} \mathrm{O}_{7}$ matrices of different surface properties, and studied the effect of the surface properties on the total conductivity as well as on the formation mechanism of the interfacial conductive phase. An effective medium approximation method was applied to the measured conductivity to analyze the interfacial conductive phase. Several $\mathrm{SiP}_{2} \mathrm{O}_{7}$ matrices of different acid property and crystalline properties were fabricated, and the conductivity of the $\mathrm{CsH}_{5}\left(\mathrm{PO}_{4}\right)_{2} / \mathrm{SiP}_{2} \mathrm{O}_{7}$ composite electrolyte was measured by AC impedance method. The acidity and crystallinity of the $\mathrm{SiP}_{2} \mathrm{O}_{7}$ matrices were found to be important properties for the formation of the interfacial conductive phase. The highest conductivity of the interfacial conductive phase was estimated to be $500 \mathrm{mS} \mathrm{cm}$, which is almost three times larger than that of the pure $\mathrm{CsH}_{5}\left(\mathrm{PO}_{4}\right)_{2}, 160 \mathrm{mS} \mathrm{cm}^{-1}$.

Keywords: Intermediate-temperature fuel cells; Cesium hydrogen phosphate; Silicon pyrophosphate; Proton conduction; Effective medium approximation 


\section{Introduction}

Fuel cells convert chemical energy directly to electrical energy with high efficiency and at low pollution levels. High energy conversion efficiency can be expected for fuel cells, since the efficiency is not confined by Carnot cycle as in the case of internal combustion engines. Fuel cells are classified according to the types of electrolytes and operating temperatures. Low-temperature types operated below $200^{\circ} \mathrm{C}$ and high-temperature types operated above $600^{\circ} \mathrm{C}$ have been actively investigated. Particularly, polymer electrolyte fuel cells (PEFCs) and solid oxide fuel cells (SOFCs) have already been commercially available in Japan. On the other hand, intermediate-temperature fuel cells (ITFCs) operative at $200-600^{\circ} \mathrm{C}$ are not fully developed because ionic conductors used as the electrolytes for ITFCs are under investigation to improve conductivity as well as thermal stability $[1,2]$. ITFCs are attractive energy conversion systems since they offer various advantages over low- and high-temperature fuel cells as follows: rapid start-up and shutdown can be possible and various kinds of materials can be used in the assembly when they are compared to the high-temperature types $[2,3,4]$, while improvements in energy conversion efficiency and superior tolerance to $\mathrm{CO}$ poisoning of the Pt electrodes are expected in comparison with low-temperature types $[5,6]$.

Phosphate-based electrolytes are promising in the intermediate temperature range, and recently relatively high proton conductivity of $1 \times 10^{-4} \mathrm{~S} \mathrm{~cm}^{-1}$ at $\mathrm{ca} .350^{\circ} \mathrm{C}$ is reported for thin membranes of phosphate glasses [7,8]. Among phosphate-based electrolytes, cesium dihydrogen phosphate, $\mathrm{CsH}_{2} \mathrm{PO}_{4}$, is known as a proton conductor to show high conductivity applicable to an intermediate temperature fuel cell $[9,10]$. The proton conductivity drastically increases from ca. $1 \times 10^{-5} \mathrm{~S} \mathrm{~cm}^{-1}$ to $1 \times 10^{-2} \mathrm{~S} \mathrm{~cm}^{-1}$ at $\mathrm{ca} .230^{\circ} \mathrm{C}$ due to the phase transition from the low-temperature to the high-temperature phase. Furthermore, an intermediatetemperature fuel cell employing this material as an electrolyte was successfully demonstrated $[11,12]$. Since $\mathrm{CsH}_{2} \mathrm{PO}_{4}$ possesses low thermal stability and mechanical strength due to the 
phase change, a matrix material is mixed with the conductive phase to form composite electrolytes [13]. Such matrix materials have mostly quite low conductivity and dilute the proton concentration in the form of composites, leading to the decrease in the conductivity of the composite electrolytes, especially in a high-temperature phase after the phase transition [14]. Unexpectedly, composite electrolytes based on $\mathrm{CsH}_{2} \mathrm{PO}_{4} / \mathrm{SiP}_{2} \mathrm{O}_{7}$ are reported to exhibit higher proton conductivity than the pure $\mathrm{CsH}_{2} \mathrm{PO}_{4}$ conductive phase in the entire temperature range from 100 to $250{ }^{\circ} \mathrm{C}[15,16,17]$. This is because $\mathrm{CsH}_{5}\left(\mathrm{PO}_{4}\right)_{2}$ phase is formed via chemical reaction between $\mathrm{CsH}_{2} \mathrm{PO}_{4}$ and $\mathrm{SiP}_{2} \mathrm{O}_{7}$, and the interaction between $\mathrm{CsH}_{5}\left(\mathrm{PO}_{4}\right)_{2}$ and $\mathrm{SiP}_{2} \mathrm{O}_{7}$ contributes to the high proton conductivity $[18,19]$. It is also indicated that an interfacial phase of high conductivity is formed at the interface of $\mathrm{CsH}_{5}\left(\mathrm{PO}_{4}\right)_{2}$ and $\mathrm{SiP}_{2} \mathrm{O}_{7}$

[18]. The precise mechanism for the high proton conduction in the interfacial phase has not been investigated systematically yet, but understanding of this interfacial layer is needed to develop effective electrolytes in the intermediate temperature range. In this study, several $\mathrm{SiP}_{2} \mathrm{O}_{7}$ matrices of different surface properties have been fabricated to investigate the effect of the surface properties on the total conductivity as well as on the formation mechanism of the interfacial conductive phase. An effective medium approximation method was applied to the measured conductivity to analyze the interfacial conductive phase.

\section{Experimental}

\section{1 $\mathrm{CsH}_{5}\left(\mathrm{PO}_{4}\right)_{2}$ and $\mathrm{SiP}_{2} \mathrm{O}_{7}$ preparation}

$\mathrm{CsH}_{5}\left(\mathrm{PO}_{4}\right)_{2}$ was prepared by drying an aqueous solution of $\mathrm{H}_{3} \mathrm{PO}_{4}$ (Sigma-Aldrich Inc.) and $\mathrm{Cs}_{2} \mathrm{CO}_{3}$ (Sigma-Aldrich Inc.) at a molar ratio of $4: 1$ at $100^{\circ} \mathrm{C}$ overnight. The $\mathrm{SiP}_{2} \mathrm{O}_{7}$ matrices were synthesized in the following manner: tetraethyl orthosilicate (TEOS, TCI) and $\left(\mathrm{NH}_{4}\right)_{2} \mathrm{HPO}_{4}$ (Sigma-Aldrich Inc.) were mixed in water-ethanol solution, so as to have a molar ratio, $\mathrm{SiO}_{2}: \mathrm{H}_{2} \mathrm{O}:\left(\mathrm{NH}_{4}\right)_{2} \mathrm{HPO}_{4}: \mathrm{CH}_{3} \mathrm{CH}_{2} \mathrm{OH}=1: 46: 2: 58$. The mixture was stirred at $70^{\circ} \mathrm{C}$ 
to $90^{\circ} \mathrm{C}$ in an oil bath and evaporated to dryness. The resultant samples were calcined at $300^{\circ} \mathrm{C}, 500^{\circ} \mathrm{C}$, or $700^{\circ} \mathrm{C}$ to obtain $\mathrm{SiP}_{2} \mathrm{O}_{7}$ matrices. The calcination temperature and calcination procedure were varied to prepare $\mathrm{SiP}_{2} \mathrm{O}_{7}$ matrices with different crystal and acidic properties. The formation of $\mathrm{SiP}_{2} \mathrm{O}_{7}$ phase was confirmed by XRD measurements.

\subsection{Electrochemical measurements}

For electrochemical measurements, the prepared powders of $\mathrm{CsH}_{5}\left(\mathrm{PO}_{4}\right)_{2}$ and $\mathrm{SiP}_{2} \mathrm{O}_{7}$ were mixed in a mortar at a desired molar ratio, and then the powder mixture was pressed uniaxially with Pt/C papers (ElectroChem Inc., Pt loading $1 \mathrm{mg} \mathrm{cm}^{-2}$ ) at $250 \mathrm{MPa}$ for $10 \mathrm{~min}$ to fabricate a $\mathrm{CsH}_{5}\left(\mathrm{PO}_{4}\right)_{2} / \mathrm{SiP}_{2} \mathrm{O}_{7}$ pellet. This membrane electrode assembly (MEA) was 10 $\mathrm{mm}$ in diameter and the electrode area was $0.5 \mathrm{~cm}^{2}$. The MEA was heat-treated at $220^{\circ} \mathrm{C}$ under $30 \% \mathrm{H}_{2} \mathrm{O} / \mathrm{Ar}$ for $1 \mathrm{~h}$. The conductivity of $\mathrm{CsH}_{5}\left(\mathrm{PO}_{4}\right)_{2} / \mathrm{SiP}_{2} \mathrm{O}_{7}$ composites was measured using AC impedance spectroscopy (Solartron 1260 frequency-response analyzer and Solartron 1287 potentiostat). The applied frequency was in the range of $0.1 \mathrm{~Hz}$ to $1 \mathrm{MHz}$ with voltage amplitude of $30 \mathrm{mV}$. The measurement was conducted at $120-220^{\circ} \mathrm{C}$ in $30 \% \mathrm{H}_{2} \mathrm{O} / \mathrm{Ar}$ flow. At each temperature, the samples were kept for 30 min until a steady state was achieved.

\subsection{Effective medium approximation}

Effective medium approximation (EMA) is a method to calculate conductivity of a multicomponent composite [20]. To evaluate the interfacial effect between $\mathrm{CsH}_{5}\left(\mathrm{PO}_{4}\right)_{2}$ and $\mathrm{SiP}_{2} \mathrm{O}_{7}$ matrix quantitatively, the conductivity of the composites were represented as a function of volume fraction of the matrix, and experimental data were curve-fitted with binary-phase EMA or ternary-phase EMA. For the case of binary-phase EMA where a conduction phase and a matrix phase are randomly mixed in a composite electrolyte and no 
interfacial effect exists between the phases, the total conductivity of the composite $\sigma_{\mathrm{m}}$ is given by the following equation:

$$
2 \sigma_{\mathrm{m}}^{2}+\left\{\left(-2 \sigma_{1}+\sigma_{2}\right) \varphi_{1}+\left(-2 \sigma_{2}+\sigma_{1}\right) \varphi_{2}\right\} \sigma_{\mathrm{m}}-\sigma_{1} \sigma_{2}=0
$$

where $\varphi_{i}$ and $\sigma_{i}$ represent the volume fraction and conductivity of $i$ phase $(i=1,2)$ in the composite, respectively. When a conduction phase and a matrix phase are mixed, and an interfacial phase with a thickness of $d$ is formed between the phases, ternary-phase EMA can be applied. When the volume fraction of matrix in a composite is $p$, then the probability of phase $i, P_{i}\left(i=0\right.$ : conductive phase such as $\mathrm{CsH}_{5}\left(\mathrm{PO}_{4}\right)_{2}, 1$ : matrix phase such as $\mathrm{SiP}_{2} \mathrm{O}_{7}, 2$ : interfacial phase, and $\left.P_{0}+P_{1}+P_{2}=1\right)$ in the composite can be given as follows:

$$
\begin{aligned}
& P_{0}=(1-p)^{m} \\
& P_{1}=p \\
& P_{2}=(1-p)\left[1-(1-p)^{m-1}\right] \\
& m=(d / a)^{3}
\end{aligned}
$$

where $a$ is a characteristic length to normalize the interfacial phase thickness. According to Furusawa et al. [21] the reduced element resistor $\rho_{\mathrm{r}}$ is introduced and can be expressed as,

$$
\frac{1}{\rho_{\mathrm{r}}}=\frac{1-(1+q)^{-2 / 3}}{\rho_{2}}+\frac{(1+q)^{-1 / 3}}{\rho_{1}+\rho_{2}\left[(1+q)^{1 / 3}-1\right]}
$$

where $q=P_{2} / P_{1}$ and $\rho_{i}$ represents the resistivity of phase $i$. Finally, the entire resistivity of the composite electrolyte $\rho^{*}$ is given by:

$$
\frac{\left(1 / \rho_{0}\right)-\left(1 / \rho^{*}\right)}{\left(1 / \rho_{0}\right)+\left(2 / \rho^{*}\right)} P_{0}+\frac{\left(1 / \rho_{0}\right)-\left(1 / \rho^{*}\right)}{\left(1 / \rho_{\mathrm{r}}\right)+\left(2 / \rho^{*}\right)}\left(P_{1}+P_{2}\right)=0
$$

By fitting Eqn. 7 to the measured conductivities of composite electrolytes for various matrix volume fractions, the thickness and conductivity of the interfacial phase can be estimated. 


\section{Results and discussion}

Calcination temperature of the matrix precursor was investigated for the formation of $\mathrm{SiP}_{2} \mathrm{O}_{7}$ phase in the matrices. When the calcination temperature was $500^{\circ} \mathrm{C}$ and $700^{\circ} \mathrm{C}$, peaks attributable to $\mathrm{SiP}_{2} \mathrm{O}_{7}$ phase were recognized with a minor crystalline phase of $\mathrm{Si}_{3}\left(\mathrm{PO}_{4}\right)_{4}$, whereas calcination at $300^{\circ} \mathrm{C}$ was insufficient for the $\mathrm{SiP}_{2} \mathrm{O}_{7}$ phase formation. Hereafter calcination at $500^{\circ} \mathrm{C}$ was adopted to prepare $\mathrm{SiP}_{2} \mathrm{O}_{7}$ matrices. Next, to vary the crystallinity of the prepared $\mathrm{SiP}_{2} \mathrm{O}_{7}$, ball-milling with a planetary ball mill (Pulverisette7, Inc. Fritch) was applied to the $\mathrm{SiP}_{2} \mathrm{O}_{7}$ matrices. The samples with ball-milling for $0 \mathrm{~h}, 5 \mathrm{~h}$ (400 rpm), and $15 \mathrm{~h}$ $(800$ rpm) are denoted as Non_mill, Mill_5h, and Mill_15h, respectively. A cylindrical vessel made of zirconia with an inner diameter of $25 \mathrm{~mm}$ and a height of $25 \mathrm{~mm}$ was used for ball milling, and the number of zirconia balls of $10 \mathrm{~mm}$ in diameter was 7 . During the ball milling the rotation direction was switched every 30 minutes. Figure 1 summarizes the XRD patterns of the ball-milled samples. It can be seen that the crystallinity of the $\mathrm{SiP}_{2} \mathrm{O}_{7}$ decreased as the

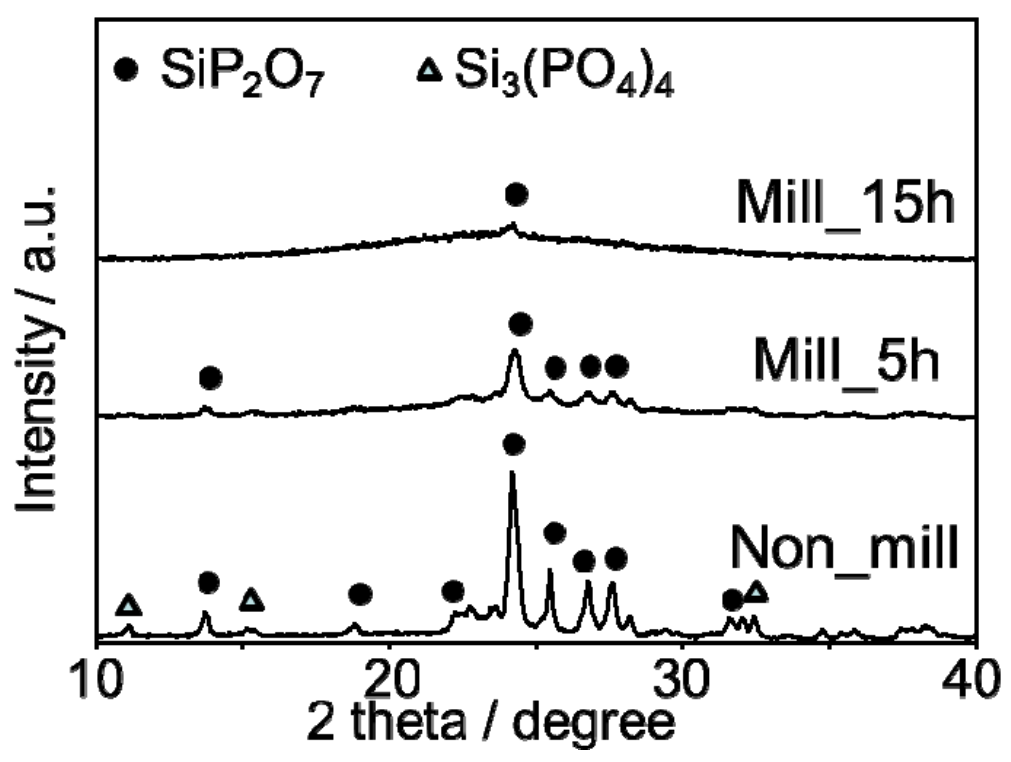

Fig. 1. XRD patterns of $\mathrm{SiP}_{2} \mathrm{O}_{7}$ matrices after ball-milling treatment: milling time $; 0 \mathrm{~h}$ (Non_mill), $5 \mathrm{~h}$ (Mill_5h), 15 h (Mill_15h). 
milling time increased. As for the BET surface area, the surface area decreased from 7 to 3 and $2 \mathrm{~m}^{2} \mathrm{~g}^{-1}$ for the increase in the milling time.

Figure 2 summarizes the conductivity of $\mathrm{CsH}_{5}\left(\mathrm{PO}_{4}\right)_{2} / \mathrm{SiP}_{2} \mathrm{O}_{7}$ composite employing the ballmilled $\mathrm{SiP}_{2} \mathrm{O}_{7}$ matrices. The molar ratio of $\mathrm{CsH}_{5}\left(\mathrm{PO}_{4}\right)_{2}$ to $\mathrm{SiP}_{2} \mathrm{O}_{7}$ was $1 / 4$. It can be seen that the conductivity of the composites decreased monotonically as the longer milling time was applied, and that the decreasing trend in the conductivity toward the temperature was more evident for the increase in the milling time. It is likely that high crystallinity of the matrix is necessary to attain high and stable conductivity. Ponomareva et al. indicated that amorphization of $\mathrm{CsH}_{2} \mathrm{PO}_{4}$ in the composite of $\mathrm{CsH}_{2} \mathrm{PO}_{4}$ and highly-crystalline $\mathrm{SiP}_{2} \mathrm{O}_{7}$ could

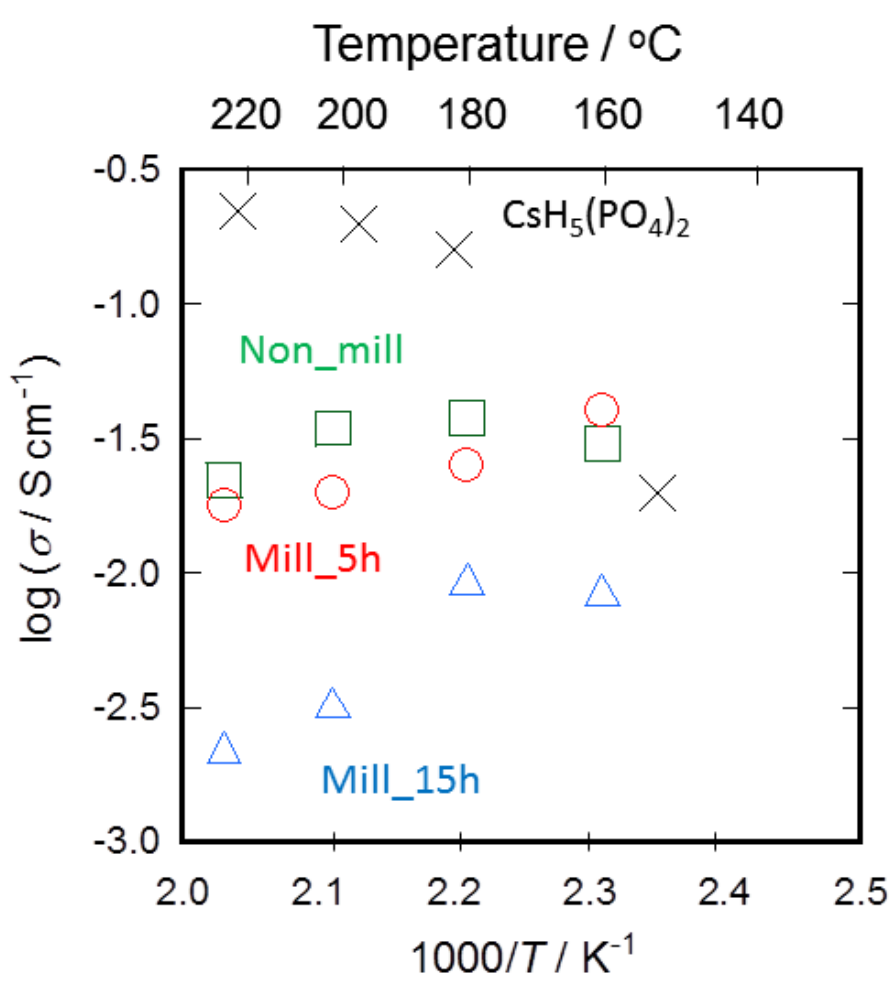

Fig. 2. The conductivity of $\mathrm{CsH}_{5}\left(\mathrm{PO}_{4}\right)_{2}$ composites using ball-milled $\mathrm{SiP}_{2} \mathrm{O}_{7}$ mattrices. Milling time; $0 \mathrm{~h}$ (Non_mill), $5 \mathrm{~h}$ (Mill_5h), $15 \mathrm{~h}$ (Mill_15h). The conductivity of pure $\mathrm{CsH}_{5}\left(\mathrm{PO}_{4}\right)_{2}$ is after Muroyama et al. [22]. 
result in enhanced conductivity and stability [17]. It is probable that a crystalline structure in the matrix is necessary for the composite electrolytes to establish an ordered arrangement of the phosphate groups at the interface, which enables protons to transfer faster via hydrogen bond network [23].

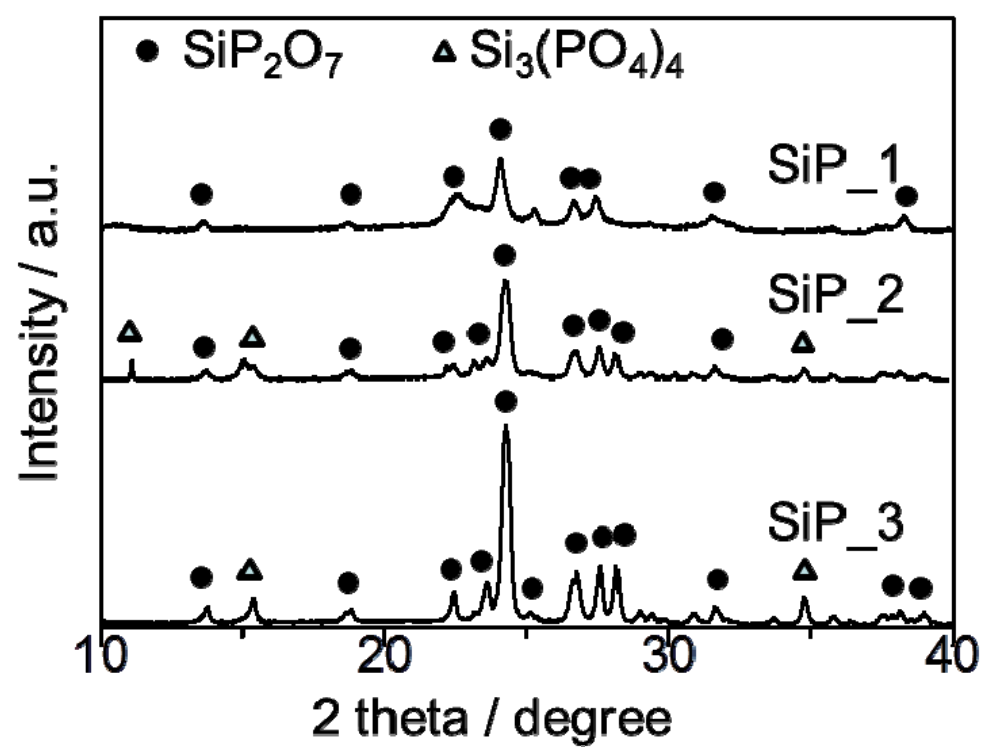

Fig. 3. XRD patterns of $\mathrm{SiP}_{2} \mathrm{O}_{7}$ matrices calcined at $500^{\circ} \mathrm{C}$ once (SiP_1), twice (SiP_2), and 3 times (SiP_3).

As the ball-milling time became long, the crystallinity of $\mathrm{SiP}_{2} \mathrm{O}_{7}$ matrices was lowered. Accordingly, in the next step the calcination procedure was varied to increase the degree of crystallinity of $\mathrm{SiP}_{2} \mathrm{O}_{7}$. The $\mathrm{SiP}_{2} \mathrm{O}_{7}$ precursor was calcined repeatedly at $500^{\circ} \mathrm{C}$ twice and three times, and the crystallinity of the samples was increased as shown in Fig. 3. The samples calcined once, twice, and three times are hereafter denoted as SiP_1, SiP_2, and SiP_3, respectively. The BET surface area of $\mathrm{SiP}_{-}$, $\mathrm{SiP}_{-}$2, and $\mathrm{SiP} 3$ was 4,8 , and $6 \mathrm{~m}^{2} \mathrm{~g}^{-1}$, respectively, so the BET surface area was almost unchanged by the repeated calcination. It can be, therefore, stated that the effect of the matrix surface area, namely, the interfacial area between the conductive phase and the matrix phase on the conductivity can be comparable. 
Figure 4 summarizes the conductivity of the composite electrolyte of $\mathrm{CsH}_{5}\left(\mathrm{PO}_{4}\right)_{2}$ and $\mathrm{SiP} \_$, SiP_2, or SiP 3 at the molar ratio of $\mathrm{CsH}_{5}\left(\mathrm{PO}_{4}\right)_{2} / \mathrm{SiP}_{2} \mathrm{O}_{7}=1 / 4$. This molar ratio has been commonly adopted to attain stable and sufficiently high conductivity of $\mathrm{CsH}_{5}\left(\mathrm{PO}_{4}\right)_{2} / \mathrm{SiP}_{2} \mathrm{O}_{7}$ composites $[15,16,18,19,22]$ and consequently the suitability of the $\mathrm{SiP}_{2} \mathrm{O}_{7}$ matrices synthesized in this study is assured since the composite electrolytes using the matrices exhibited a comparable conductivity. As the degree of the crystallinity of the matrix increased, the conductivity of the composite was raised, indicating that high crystallinity is requisite to enhance the conductivity of the composite electrolyte. It is of note that the conductivities of the SiP_2 and SiP_3 composites increased as the temperature was raised, whereas that of the SiP_1 composite decreased rapidly above $180^{\circ} \mathrm{C}$. This can be because a weak interaction between $\mathrm{CsH}_{5}\left(\mathrm{PO}_{4}\right)_{2}$ and SiP_1 prevented the $\mathrm{CsH}_{5}\left(\mathrm{PO}_{4}\right)_{2}$ conductive phase in a molten state,

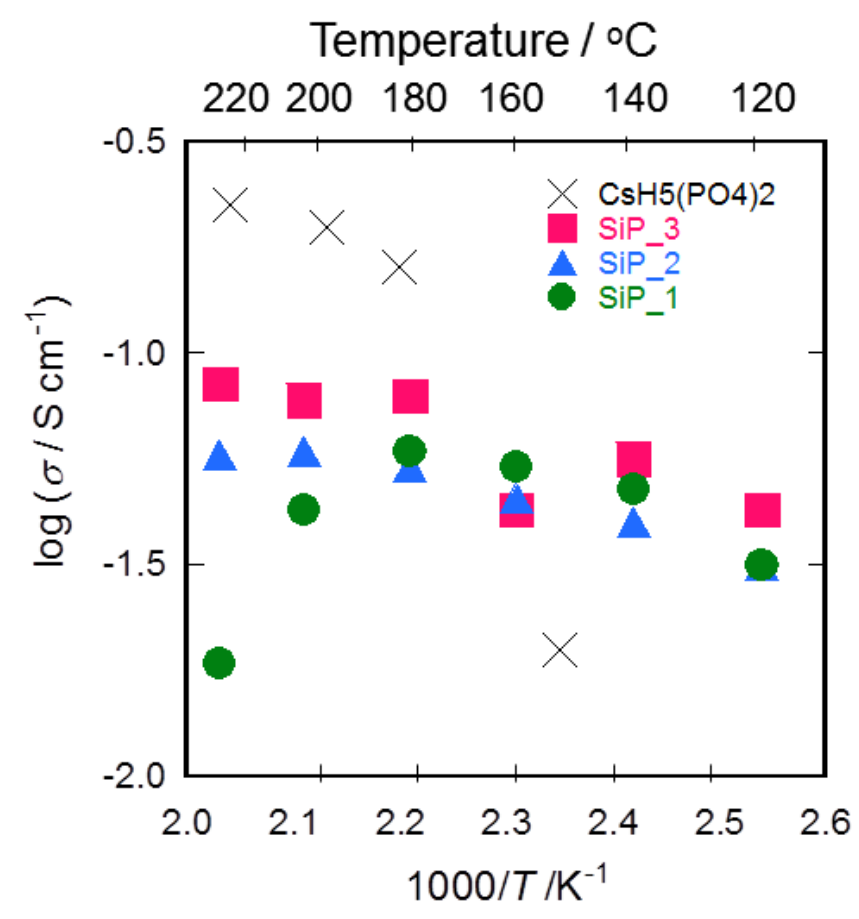

Fig. 4. The conductivity of $\mathrm{CsH}_{5}\left(\mathrm{PO}_{4}\right)_{2}$ composites using $\mathrm{SiP}_{2} \mathrm{O}_{7}$ mattrices calcined at $500^{\circ} \mathrm{C}$ once (SiP_1), twice (SiP_2), and 3 times (SiP_3). The conductivity of pure $\mathrm{CsH}_{5}\left(\mathrm{PO}_{4}\right)_{2}$ is after Muroyama et al. [22]. 
of which the eutectic point is around $150^{\circ} \mathrm{C}$, from residing on the interfacial area. This is supported by the experimental findings by Muroyma et al. [19] that when matrices possess weak interaction with $\mathrm{CsH}_{5}\left(\mathrm{PO}_{4}\right)_{2}$, the wettability of $\mathrm{CsH}_{5}\left(\mathrm{PO}_{4}\right)_{2}$ to the matrices is not so good and thus $\mathrm{CsH}_{5}\left(\mathrm{PO}_{4}\right)_{2}$ tends to have an point contact with the matrices. As a consequence, $\mathrm{CsH}_{5}\left(\mathrm{PO}_{4}\right)_{2}$ phase in its molten state does not spread over the interfacial area but tends to agglomerate, leading to gradual loss of connection in the $\mathrm{CsH}_{5}\left(\mathrm{PO}_{4}\right)_{2}$ phase. For the conductivity of the SiP_2 and SiP_3 composite electrolytes, $61 \mathrm{mS} \mathrm{cm}^{-1}$ and $78 \mathrm{mS} \mathrm{cm}^{-1}$ were measured, respectively, which is larger than $50 \mathrm{mS} \mathrm{cm}^{-1}$ reported in the previous study [16]. It is, therefore, concluded that the high crystallinity of the $\mathrm{SiP}_{2} \mathrm{O}_{7}$ matrix is requisite for the stable and high conductivity of the composite electrolyte. 
To attain the further insight into the interfacial conductive phase, effective medium approximation was applied to the conductivities measured by changing the volume fraction of the $\mathrm{SiP}_{2} \mathrm{O}_{7}$ matrix in the composite electrolytes. Figure 5 shows the conductivities measured at $200^{\circ} \mathrm{C}$ for the SiP_1 and SiP_2 composites and fitting curves to the measured data using the binary-phase EMA. It can be seen that the binary-phase EMA is well fitted to the conductivity of the SiP_1 composite, but not to that of the SiP_2 composite. The binary-phase fitting also failed in the case of the SiP_3 composite (the results are not shown). The deviation between the fitting and the measured values is more evident at large matrix volume fractions where the
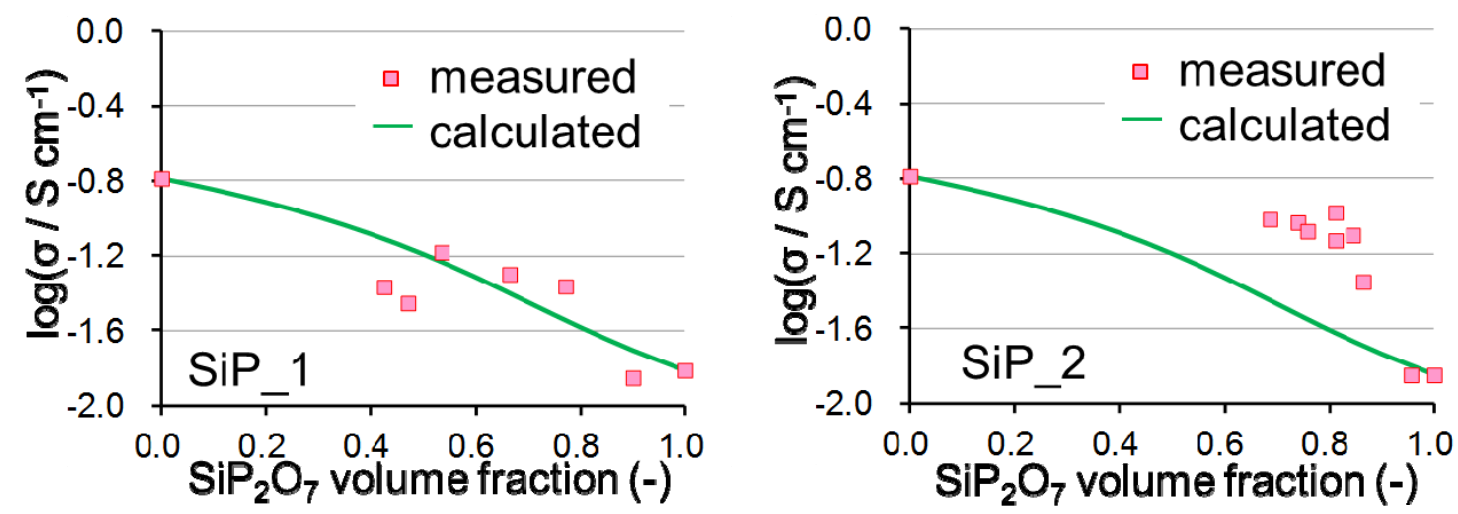

Fig. 5. Binary-phase effective medium approximation fitting to the conductivities measured at $200^{\circ} \mathrm{C}$ for the $\mathrm{CsH}_{5}\left(\mathrm{PO}_{4}\right)_{2} / \mathrm{SiP}_{2} \mathrm{O}_{7}$ composites using $\mathrm{SiP} \_1$ and $\mathrm{SiP} \_2$ with different $\mathrm{SiP}_{2} \mathrm{O}_{7}$ volume fractions.
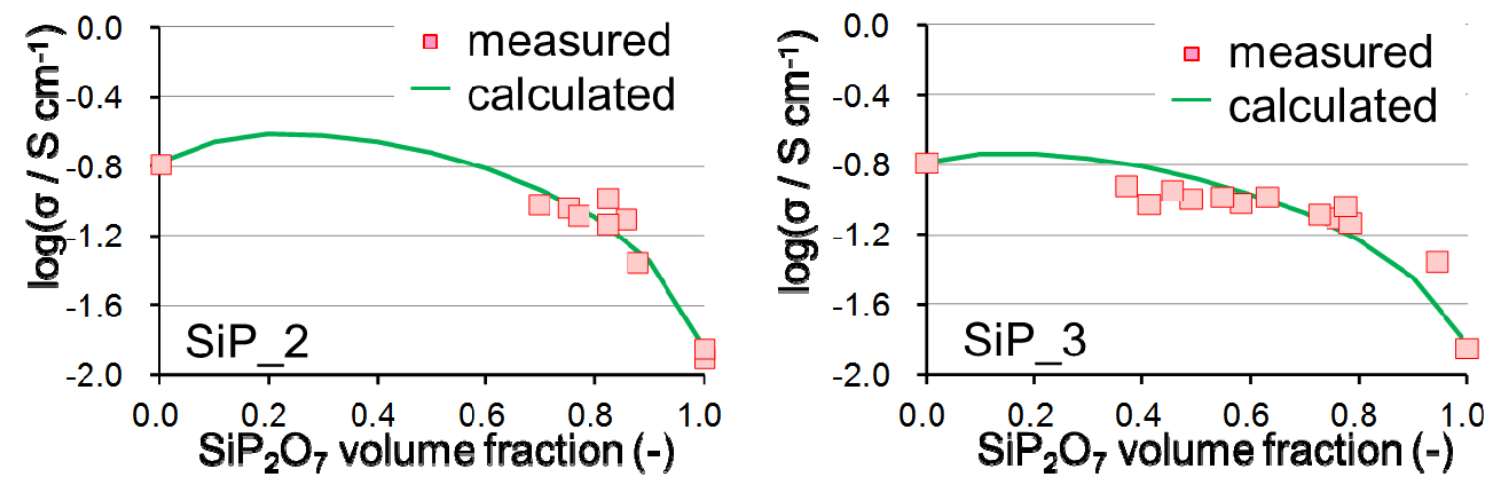

Fig. 6. Ternary-phase effective medium approximation fitting to the conductivities measured at $200^{\circ} \mathrm{C}$ for the $\mathrm{CsH}_{5}\left(\mathrm{PO}_{4}\right)_{2} / \mathrm{SiP}_{2} \mathrm{O}_{7}$ composites using $\mathrm{SiP} \_2$ and $\mathrm{SiP} \_3$ with different $\mathrm{SiP}_{2} \mathrm{O}_{7}$ volume fractions. 
interfacial effect should be evident since the surface area of the matrix per unit volume of the composite electrolytes is high. On the other hand, the ternary-phase EMA is fitted well to the conductivities of the SiP_2 and SiP_3 composites, as shown in Fig. 6. These results indicate that an interfacial conductive phase exists in the composites using SiP_2 and SiP_3. From the fitting by the ternary-phase EMA under the assumption of a constant $m$ value in Eqn. (5), the conductivities of the interfacial phase in the composites with SiP_2 and SiP_3 were estimated to be $500 \mathrm{mS} \mathrm{cm}^{-1}$ and $330 \mathrm{mS} \mathrm{cm}$, respectively, which is much higher than the pure $\mathrm{CsH}_{5}\left(\mathrm{PO}_{4}\right)_{2}$ conductivity of $160 \mathrm{mS} \mathrm{cm}{ }^{-1}$. Note that pure $\mathrm{SiP}_{2} \mathrm{O}_{7}$ possesses a conductivity of ca. $10 \mathrm{mS} \mathrm{cm} \mathrm{c}^{-1}$ and thus does not contribute to the total conductivity of the composite electrolytes.

Furthermore, the surface acidic property of the $\mathrm{SiP}_{2} \mathrm{O}_{7}$ matrices was studied by temperatureprogramed desorption of ammonia. In this method, $\mathrm{NH}_{3}$ adsorbs on the acidic sites of matrices and desorbs by heating under inert atmosphere. The peak temperature of the $\mathrm{NH}_{3}$ desorption designates the acid strength and the $\mathrm{NH}_{3}$ desorption amount quantifies the acid amount of the materials. The samples were pretreated at $450^{\circ} \mathrm{C}$ by flowing $\mathrm{He}$ in $1 \mathrm{~h}$ for $\mathrm{SiP} \_1$ and $\mathrm{SiP} \_3$, and in $2 \mathrm{~h}$ for $\mathrm{SiP} \_2$, depending on the adsorbed $\mathrm{H}_{2} \mathrm{O}$ amount determined beforehand by thermogravimetric analysis. Then, the temperature was decreased to $100^{\circ} \mathrm{C}$ and subsequently He flow was switched to $\mathrm{NH}_{3}$ flow for 15 min of $\mathrm{NH}_{3}$ adsorption, followed by removal of physically adsorbed $\mathrm{NH}_{3}$ in He flow for $30 \mathrm{~min}$. Finally, the temperature was raised at a heating rate of $10^{\circ} \mathrm{C} \min ^{-1}$ for $\mathrm{NH}_{3}$ desorption. Figure 7 displays the $\mathrm{NH}_{3}$ desorption profiles from the $\mathrm{SiP}_{2} \mathrm{O}_{7}$ samples such as $\mathrm{SiP} \_$, $\mathrm{SiP} \_$2, and $\mathrm{SiP} \_$. The desorption peak appeared at ca. $250^{\circ} \mathrm{C}$ for the SiP_2 and SiP_3, which indicates the acid strength is identical, whereas the acid amount was larger for SiP_2. The larger acid amount implies that the number of the acid sites, namely $\mathrm{P}-\mathrm{OH}$ groups, is larger on SiP_2 than SiP_3. This is possibly because dehydration could be progressed over SiP_3 due to the longer calcination 
time in total and eventually the number of $\mathrm{P}-\mathrm{OH}$ groups on SiP_3 decreased compared with SiP_2. As mentioned above, the higher conductivity of the interfacial phase was estimated for the composite with the SiP_2 matrix, which coincides with the larger acid amount in Fig. 7. Consequently, it is highly likely that due to the larger number of the acidic sites protons can move more frequently on the acidic sites with lower activation energy, leading to the formation of the new interfacial conductive phase. On the other hand, for SiP_1 almost no peak was detected in Fig. 7. Along with the results in binary-phase EMA in Fig. 5, an interfacial conductive phase was not formed when $\mathrm{SiP}_{-} 1$ was used as a matrix for the composite electrolyte.

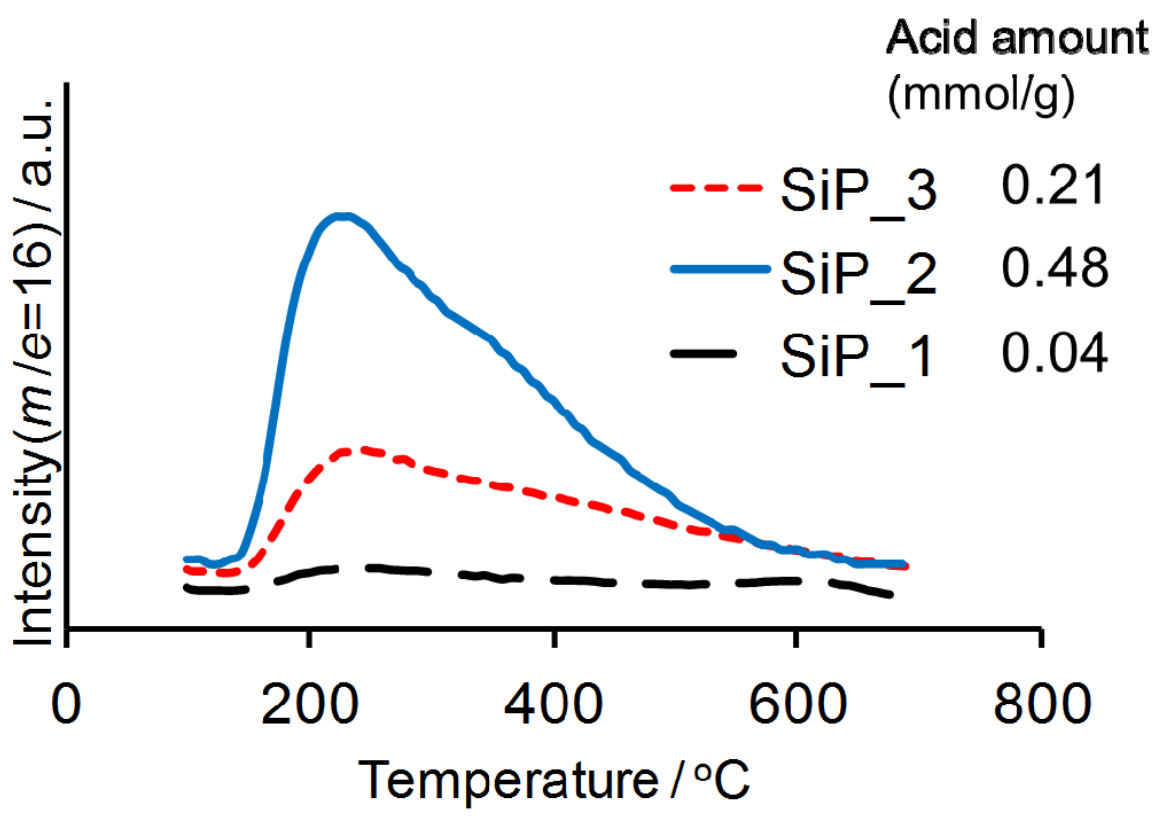

Fig. 7. Temperature programmed desorption of anmonia from $\mathrm{SiP}_{2} \mathrm{O}_{7}$ mattrices calcined at $500^{\circ} \mathrm{C}$ once (SiP_1), twice (SiP_2), and 3 times (SiP_3). 


\section{Conclusions}

Several $\mathrm{SiP}_{2} \mathrm{O}_{7}$ matrices of different surface properties were prepared to fabricate $\mathrm{CsH}_{5}\left(\mathrm{PO}_{4}\right)_{2} / \mathrm{SiP}_{2} \mathrm{O}_{7}$ composite electrolytes, and the effect of the matrix surface properties was studied on the total conductivity as well as on the formation mechanism of the interfacial conductive phase. It was found that the crystallinity as well as the acid amount of $\mathrm{SiP}_{2} \mathrm{O}_{7}$ matrices played an important role in the interfacial phase formation. The highest conductivity of the interfacial conductive phase was estimated to be $500 \mathrm{mS} \mathrm{cm}^{-1}$ by ternary-phase effective approximation, and is much larger than that of the pure $\mathrm{CsH}_{5}\left(\mathrm{PO}_{4}\right)_{2}$.

\section{Acknowledgments}

This work was supported by CREST, JST, and Grants-in-Aid for Scientific Research (JSPS KAKENHI) Grant Number 22360336.

\section{References}

1) S.M. Haile, D.A. Boysen, C.R.I. Chisholm, R.B. Merle, Nature, 410, 910-913(2001).

2) J. Xiao, H. Zhang, Z. Yang, H. Wang, G. Ma, Z. Zhou, J. Alloy. Compd., 521, 106-111 (2012).

3) T. Norby, Nature, 410, 877-878 (2001).

4) M.W. Louie, S.M. Haile, Energy Environ. Sci., 4, 4230-4238 (2011).

5) M. Nagao, A. Takeuchi, P. Heo, T. Hibino, M. Sano, A. Tomita, Electrochem. Solid State Lett., 9, A105-A109 (2006).

6) M. Mamlouk, J.H. Jang, K. Scott, J. Fuel Cell Sci. Technol., 9, 1-9 (2012).

7) J.E. Kim, S.B. Park, Y.I. Park, Solid State Ionics, 216, 15-18 (2012).

8) T. Ishiyama, S. Suzuki, J. Nishii, T. Yamashita, H. Kawazoe, T. Omata, Solid State Ionics, 262, 856-859 (2014).

9) A. I. Baranov, B. V. Merinov, A. V. Tregubchenko, V. P. Khiznichenko, L. A. Shuvalov, N. M. Schagina, Solid State Ionics, 36, 279-282 (1989).

10) W. Bronowska, J. Chem. Phys., 114, 611 (2001).

11) D. A. Boysen, Y. Uda, C. R. I. Chisholm, S. M. Haile, Science, 303, 68-70 (2004).

12) T. Uda, S.M. Haile, Electrochem. Solid-State Lett., 8, A245-A246 (2005).

13) G. Qing, R. Kikuchi, A. Takagaki, T. Sugawara, S. T. Oyama, J. Electrochem. Soc., 161, F451-F457 (2014).

14) S. Wang, J. Otomo, M. Ogura, C. Wen, H. Nagamoto, H. Takahashi, Solid State Ionics, 176, 755-760 (2005). 
15) T. Matsui, T. Kukino, R. Kikuchi, K. Eguchi, Electrochem. Solid-State Lett., 8, A256A258 (2005).

16) T. Matsui, T. Kukino, R. Kikuchi, K. Eguchi, J. Electrochem. Soc., 153, A339-A342 (2006).

17) V. G. Ponomareva, E. S. Shutova, G. V. Lavrova, Inorg. Mater., 44, 1009-1014 (2008).

18) T. Matsui, T. Kukino, R. Kikuchi, K. Eguchi, Electrochim. Acta, 51, 3719-3723 (2006).

19) M. Muroyama, T. Matsui, R. Kikuchi, K. Eguchi, J. Phys. Chem. C, 112, 15532-15536 (2008).

20) N. Cusack, The Physics of Structurally Disordered Matter: an Introduction, Adam Hilger, GBR, 1987.

21) S. Furusawa, S. Miyaoka, Y. Ishibashi, J. Phys. Soc. Jpn., 60, 1666-1671 (1991).

22) H. Muroyama, K. Kudo, T. Matsui, R. Kikuchi, K. Eguchi, Solid State Ionics, 178, $1512-$ 1516 (2007).

23) D.A. Boysen, S.M. Haile, H. Liu, R.A. Secco, Chem. Mater., 15, 727-736 (2003). 